Indonesian Journal of Biotechnology, December 2015

Vol. 20, No. 2, pp.152-160

\title{
The effect of methanol extract of soybean seeds (Glycine max L.Merr.) on the histology and immunohistochemical distribution of Cyp19 aromatase in rat testis (Rattus norvegicus L.)
}

\author{
Retno Aryani ${ }^{1,2^{*}}$, Sukarti Moeljopawiro ${ }^{2}$, Laurentius Hartanto Nugroho ${ }^{3}$, Pudji Astuti ${ }^{4}$
}

\author{
${ }^{1}$ Department of Biology, Faculty of Mathematics and Science, Universitas Mulawarman, Samarinda, \\ Indonesia \\ ${ }^{2}$ Department of Biochemistry, Faculty of Biology, Universitas Gadjah Mada, Yogyakarta, Indonesia \\ ${ }^{3}$ Department of Plant Anatomy, Faculty of Biology, Universitas Gadjah Mada, Yogyakarta, Indonesia \\ ${ }^{4}$ Department of Physiology, Faculty of Veterinary Medicine, Universitas Gadjah Mada, Yogyakarta, \\ Indonesia
}

\begin{abstract}
Soybean (Glycine max L. Merr.) contains phytoestrogens that have a chemical structure resembling estrogen in the body. They function like estrogen and antiestrogen, affecting the metabolism of sex steroid hormones. This research aimed to determine the effect of the methanol extract of soybean on the histological structure and distribution of immunohistochemical Cyp19 aromatase in rat testis . Twenty males of Wistar rats were divided into 4 groups of 5 . The first group was the control and the second to fourth groups were given soybean extract $(250 \mathrm{mg} / \mathrm{kg}$ of body weight, $500 \mathrm{mg} / \mathrm{kg}$ of body weight) and genistein $(0.3 \mathrm{mg} / \mathrm{kg}$ of body weight), respectively, for 52 days. The results of this study indicate that the effect of methanol extract from soybean caused weight gain, and the weight of the testis and epididymis decreased. In addition, the histological results showed that seminiferous tubules were reduced in size, became irregular, were separated by a wide interstitium, and spermatogenic cells were decreased. The immunohistochemical results showed that the expression of Cyp19 aromatase in the rats decreased both in spermatocyte cells and Leydig cells. It could be concluded that the methanol extract of soybean induced testicular damage and reduced Cyp19 aromatase expression in rat testis.
\end{abstract}

Keywords: Soybean (Glycine max L. Merr.), Genistein, Cyp19 aromatase, testis, male rats

\section{Introduction}

Androgens had long been considered as a male sex hormone while estrogen as a hormone of the female sex. However, in both sexes, androgens are metabolized into estrogen and there is plenty of evidence indicating that both of these hormones play an important role in the regulation of physiological functions in males and females. However, excess exposure to estrogen may interfere with male reproductive functions (Giwercman, 2011). In Leydig

\section{*Corresponding author:}

Retno Aryani Department of Biology, Faculty of Mathematics and Science, Universitas Mulawarman, Samarinda, Indonesia. Telp. +62 81253937321

Email address: retno_ar@yahoo.co.id cells, testosterone is partly metabolized into estradiol by aromatase. This enzyme sustains the balance between testosterone and estradiol testis levels. Testosterone is essential for several physiological processes in humans. Some biological effects are mediated through the aromatization of testosterone into estradiol (Carani et al., 2005; Motofei and Rowland, 2005; Bilińska et al., 2006). Aromatase seems to be found in a variety of tissues, and its activity is essential for male reproductive functions (Rochira et al., 2007; Carreau et al., 2007).

Although there has long been evidence that the development of the reproductive tract of males is influenced by the action of estrogen (Carreau et al., 2008; Prince and Korach, 2008; Ellem and Risbridger, 2009), 
the role of estrogen in reproductive is rarely studied. Recently, there has been an increasing public concern that exposure to chemicals in the environment can affect the endocrine and reproductive systems. Exposure to estrogenic chemicals results in a number of disorders, including reducing the size of the gonads, spermatogenesis disorder, and decreasing the number and quality of sperm. The estrogenic activity had been associated with a variety of steroidal and non-steroidal compounds, including a phytoestrogen, such as genistein and daidzen (Rice and Whitehead, 2006).

Plants produce phytoestrogen, which can function as estrogen. Phytoestrogens can be classified as isoflavones, coumestan, and lignin. Isoflavone is the kind of phytoestrogen that is mostly found in soybeans. The primarily isoflavonesinsoybeanare genistein and daidzein (Kim and Park, 2012). Phytoestrogen does not only have a variety of beneficial physiological effects; it can also have a detrimental effect primarily on the reproductive tract of most animal species. Many phytoestrogens can react as an agonist or antagonist of estrogen that affects the metabolism of sex hormones and is related to biological activity. The effect can vary from an excessive estrogen response, so it can increase the secretion in the reproductive tract, infertility, and also change the behavior of animals. Therefore, a lot of phytoestrogens are known as endocrine disruptor compounds because they may interfere with the synthesis, secretion, transport, binding, action, or diminish the natural hormones in the body that are responsible for reproduction (Marquez et al., 2012). The objective of this study was to determine the effect of the methanol extract of soybean on the histology and immunohistochemistry distribution of Cyp19 aromatase in rat testis.

\section{Materials and Methods Materials}

Soybeans (Glycine max L. Merr.) were obtained from Balitkabi (Balai Penelitian Aneka Tanaman Kacang dan Umbi ) Malang, Indonesia.

\section{Soybean extract preparation}

Soybeans were dried and crushed into powder. Of this soy powder, $100 \mathrm{~g}$ was then defatted by soaking in $200 \mathrm{ml}$ of $\mathrm{n}$-hexane. The non fat soy powder was dried overnight and subsequently extracted with the maceration method using methanol $80 \%$ with a ratio of 1:5 for $2 \times 24$ hours. The solution was filtered and then the pellets were dried using a waterbath until a concentrated extract was obtained. Finally, the extract was stored in a refrigerator until the in vivo tests.

\section{Ethical clearance}

The methods used in this study were approved by the Ethical Commission of the Integrated Research and Testing Laboratory, Universitas Gadjah Mada, No. 279/KECLPPT/VI/2015.

\section{Animal Studies}

Twenty males of Wistar rat (Rattus norvegicus L.) weighing 100-150 g from LPPT Unit IV UGM were used. The animals were acclimatized under laboratory conditions (12:12h day/night cycle at a temperature of $25^{\circ} \mathrm{C} \pm 2$ ) for 1 week. Standard pellets and water were given ad libitum. The rats were weighed and divided into 4 groups of 5 . The first group served as the control, while the second to fourth groups were given soybean extract $(250 \mathrm{mg} / \mathrm{kg}$ of body weight, 500 $\mathrm{mg} / \mathrm{kg}$ of body weight) and genistein (0.3 $\mathrm{mg} / \mathrm{kg}$ of body weight), respectively, for 52 days. At the end of treatment, the animals were sacrificed by euthanasia, weighed, and dissected. The testis and epididymis were taken and weighed, after which the testis was fixed using 10\% formalin. After fixation, the specimens were dehydrated in graded alcohol, cleared with xilol and embedded in paraffin. Sections with a thickness of 6 microns were cut using a rotary microtome and mounted on glass objects. For histological analysis, the slices were stained with hematoxylin eosin. Meanwhile, for the immunohistochemical analysis, the previous slides were deparafinnized and blocked 
using hydrogen peroxide for 15 minutes and then blocked with normal serum for 15 minutes. Furthermore, it was incubated with anti-Cyp19 aromatase antibody overnight at $4^{\circ} \mathrm{C}$. After being washed 3 times using PBS, it was incubated with secondary antibody for 15 minutes. The slide was dripped with Diaminobenzidine (DAB) chromogen, counterstained with hematoxylin, dehydrated and covered with a glass lid. The results of staining were observed under a microscope using magnifications of 40 and 100.

\section{Results and Discussion \\ Weight of body, testis, and epididmis}

Male rats' body weight, testis and epididymis weight, and weight ratio of organ/BW (Body Weight) after 52 days of being given methanol extract from soybean is shown in Table 1.

Table 1 shows that the methanol extract of soybean seeds affects the growth and development of male rats' body weight. Changes in body weight indicates the status of an animal's health (Hilaly et al., 2004). The weight of treatment groups in final studies decreased significantly than control rats. According to Weber et al. (2001), estrogen is known to alter eating behavior, weight, and significantly improve locomotor behavior in mice. Furthermore, it has been known that phytoestrogens transfer into the brain tissue and have physicochemical and physiological characteristics similar to endogenous estrogen.

Table 1 also shows that the extract caused a significant reduction $(\mathrm{P}<0.05)$ of the weight of the testis and epididymis in the treatment groups compared with control groups. This decrease was likely due to abnormal spermatogenic activity that was caused by the active compounds in the extract. Testis weight depends on the mass of differentiated spermatogenic cells (Kianifard et al., 2013), probably due to the decreasing number of germ cells, and inhibition of spermatogenesis and spermatogenic enzyme activity (Sakr \& Al-Amoudi, 2012). Elements of the tubules and testicular germ make up approximately $98 \%$ of testicular mass. The decline in the number of spermatogenic cells found in the treated group caused a decrease in testicular weight (Kachhawa et al., 2012). However, the ratio or relative weight of testis and epididymis to body weight increased in the treatment groups. The relative weight of the organs can be used as an indicator of important empirical deviation from normal (or decrease in efficiency) in most of the body organ systems. The high ratio of organ weight to body weight is an indicator of weight loss in the treatment groups (Kianifard et al., 2013).

Table 1. Body, testis, and epididymis weight, and weight ratio of organ/BWof male rats after 52 days of being given methanol extract from soybean.

\begin{tabular}{|c|c|c|c|c|c|c|}
\hline Group & \multicolumn{4}{|c|}{ Weight (gram) } & \multirow{2}{*}{$\begin{array}{c}\text { Ratio of } \\
\text { testis } \\
\text { W eight/BW } \\
(\%)\end{array}$} & \multirow{2}{*}{$\begin{array}{c}\text { Ratio of } \\
\text { epididymis } \\
\text { Weight/BW } \\
(\%)\end{array}$} \\
\hline (SE mg/kgbw) & Initial of BW & Final of BW & Testis & Epididymis & & \\
\hline 0 & $124.5 \pm 0.76^{\mathrm{a}}$ & $283.9 \pm 0.23^{\mathrm{a}}$ & $2.54 \pm 0.03^{\mathrm{a}}$ & $1.06 \pm 0.03^{\mathrm{a}}$ & 0.9 & 0.37 \\
\hline 250 & $125.6 \pm 2.64^{\mathrm{a}}$ & $254.4 \pm 3.18^{b}$ & $2.42 \pm 0.01^{b}$ & $0.95 \pm 0.04^{b}$ & 0.95 & 0.37 \\
\hline 500 & $127.6 \pm 2.08^{\mathrm{a}}$ & $254.9 \pm 1.82^{\mathrm{b}}$ & $2.40 \pm 0.01^{\mathrm{b}}$ & $0.80 \pm 0.01^{\mathrm{c}}$ & 0.94 & 0.31 \\
\hline $\begin{array}{c}\text { Genistein } 0,3 \\
\mathrm{mg} / \mathrm{kgbw}\end{array}$ & $124.7 \pm 2.84^{\mathrm{a}}$ & $254.1 \pm 1.7^{\mathrm{b}}$ & $2.41 \pm 0.08^{b}$ & $0.79 \pm 0.01^{\mathrm{c}}$ & 0.95 & 0.31 \\
\hline
\end{tabular}

The numbers followed by the same letter on each column are not significantly different $(n=5, p>0.05)$. SE: Soy Extract. 


\section{Testis Structure}

The testicular histology of both the control and treatment groups can be seen in Figure 1, and clearly shows that there was a difference between the control and treatment groups. In the control group, the structure of the seminiferous tubules and interstitial tissue were normal. The seminiferous tubules were adjacent to each other and seemed to produce a normal spermatogenesis, seminiferous epithelium height, and narrow lumen. Interstitial tissue seemed cramped with some Leydig cells (Figure 1.A).

In the treatment groups (Figure 1. B, C, and $\mathrm{D})$, the seminiferous tubules were reduced in size, became irregular, were separated from each other by wide interstitial tissue, and spermatogenic cells were decreased. Extensive areas of interstitial space formed due to a reduction in diameter and tubular atrophy (Sajjad, 2012). Interstitial tissue and Leydig cells also seem to be less degenerated and necrotic. These findings were in accord with the results on testis weight that were obtained in the treatment group.This may be due to the decreasing number of germ cells and testosterone levels that result in the inhibition of spermatogenesis. It can be concluded that the inhibition of spermatogenic cells is due to the decrease in testosterone through downregulation of steroidogenesis and damaged Leydig cells (Ghosh et al., 2002). This indicates that soy extract causes testicular histopathological changes and inhibition of spermatogenesis.

The role of estrogen in male fertility is included in the regulation of germ cell development or spermatogenesis on rats which is lacking the aromatase (Robertson et al.,1999). Estrogen also affects male germ cells directly, managing storage and Fos protein phosphorylation in the cytoplasm and nuclei of germ cells. It has been suggested that estrogen may be involved in the mechanism of induced proliferation of spermatogonia (Cobellis et al., 2002). According to Assinder
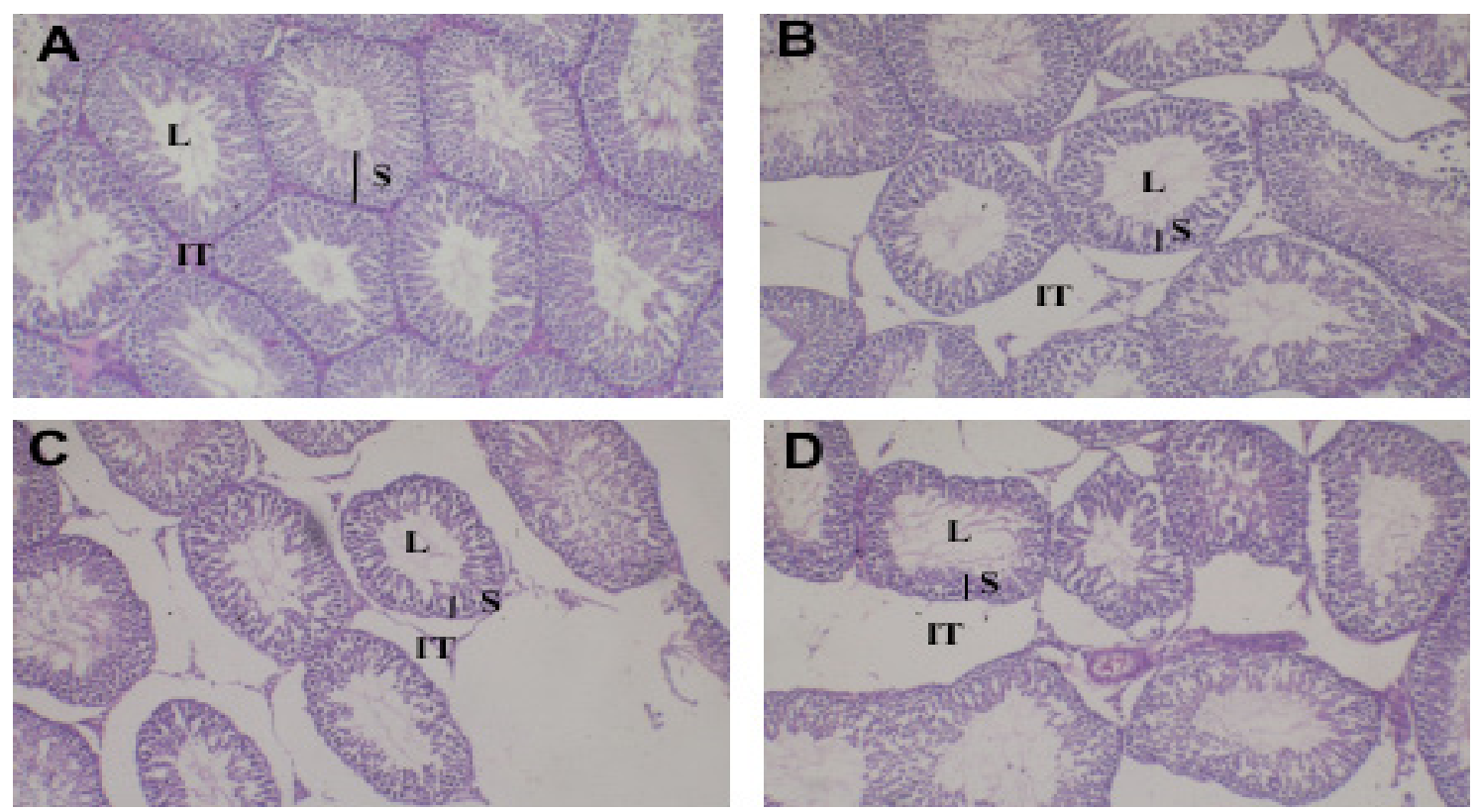

Figure 1. Structure of the testis, HE staining, magnification 100x lens.

A. Control group; normal seminiferous tubules with spermatogenesis active and separated by a narrow interstitial tissue. B. treatment of soybean extract $(250 \mathrm{mg} / \mathrm{kg} \mathrm{bw})$, C. treatment of soybean extract $(500 \mathrm{mg} /$ $\mathrm{kg} \mathrm{bw}), \mathrm{D}$. treatment of genistein $(0.3 \mathrm{mg} / \mathrm{kg} \mathrm{bw})$. All three treatments resulted in seminiferous tubules that were smaller, irregular, and separated from one another by wide interstitial tissue, while spermatogenic cells decreased. S: spermatogenic cells, IT: Interstitial tissue and Leydig, L: lumen. 
et al. (2007), the treatment of phytoestrogens in male rats caused a reduction in sperm count and spermatids, but the diameter of seminiferous tubules lumen increased significantly, disturbing spermatogenesis by increasing apoptosis of germ cells.

\section{Aromatase Expression with Immunohistochemical (IHC)}

The expression of CYP19 aromatase was not only observed using a Western blot (data not shown) in order to determine the level of aromatase expression but also by immunohistochemical staining to determine the location and level of immunostaining expression aromatase in the testis (Table 2).

Table 2. Expression of aromatase protein in testis.

\begin{tabular}{lc}
\hline \multicolumn{1}{c}{ Group } & $\begin{array}{c}\text { Expression of aromatase } \\
\text { on spermatogenic cells } \\
\text { and Leydig cells }\end{array}$ \\
\hline Control & +++ \\
soy extract $250 \mathrm{mg} / \mathrm{kgBB}$ & ++ \\
soy extract $500 \mathrm{mg} / \mathrm{kgBB}$ & + \\
Genistein $0,3 \mathrm{mg} / \mathrm{kgBB}$ & + \\
\hline
\end{tabular}

Description: $+++=$ strong,$++=$ moderate,$+=$ weak..

CYP19 aromatase expression was observed in the testis by immunohistochemical staining. The immunohistochemistry results revealed that the soybean extract decreased the expression of aromatase in rat testis. Aromatase expression in the control group was stronger and more abundant than the treatment groups (Figure 1. A). In the treatment groups, the imunoexpression of aromatase was less and weak (Figure 2.B, C, and D).

The results of imunoexpression showed that positive aromatase was detected in Leydig cells and spermatogenic cells. According to Ballack et al. (2005) aromatase immunostaining was detected in Leydig cells and the cells of aromatase spermatogenic. Aromatase expession was detected in SertoliLeydig cells, spermatogonia, spermatocytes, spermatids, and spermatozoa elongated in adult mice (Carreau et al., 2002), and SertoliLeydig cells, spermatocytes, spermatids, and spermatozoa in humans (Carreau et al., 2008).

In Leydig cells, the testosterone is partly metabolized into estradiol by aromatase. This enzyme sustains the balance between testosterone and estradiol levels in the testes. Estradiol is also important in the development and maintenance of reproductive functions in human males with regard to animal deficiency in the estrogen receptor gene or aromatase gene (Carani et al., 2005; Carreau 2008; Nantia et al., 2011). Therefore, it can be said that estrogen plays a regulatory role in the reproductive tract of men because of the disruption of aromatase expression and estrogen biosynthesis in the testes. And the absence of the estrogen receptor (ER) can cause disturbances in spermatogenesis and steroidogenesis (O'Donnell et al., 2001).

Dietary genistein caused a downregulation of aromatase mRNA in the testis although it remains unclear whether the inhibition of aromatase activity is the result of the competition of genistein on the active side or decreasing aromatase activity regulation of protein translation (Fritz et al., 2003). The structural similarity between genistein and endogenous steroidogenic substrate is postulated as a mechanism of competitive inhibition of the active site of the steroidogenic enzyme (Ohno et al., 2002). It is possible the changes in the enzyme activity did not depend on changes in mRNA and protein levels but rather the availability of different substrates or changes in the microenvironment. According to Mesiano et al. (1999), altered P450c21 enzymatic activities due to isoflavones could not be explained by corresponding changes in expression, and it was proposed that this was due to the upstream $3 \beta$-HSD inhibition that lowered the amount of substrate available for P450c21. Alternatively, it had been shown that isoflavones can be bound to and modify the membrane environment. The structural changes of the microsomal membranes in the surrounding area of steroidogenic enzymes such as $3 \beta-$ HSD can affect the activity of the enzyme (Arora et al., 2000). 

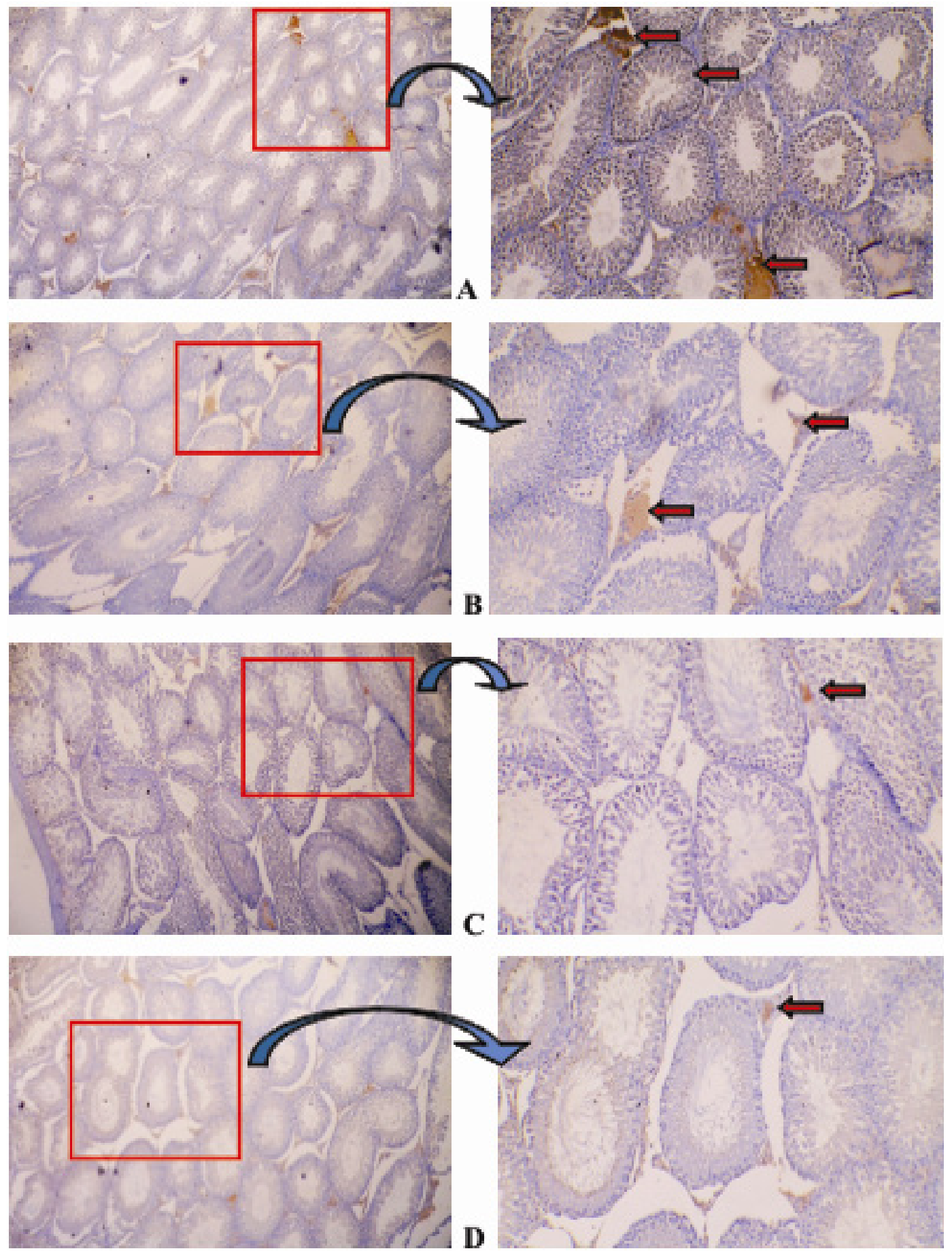

Figure 2. Structure of the testis, IHC staining, magnification with 40x lens (left) and 100x (right).

A. control, B. soybean extract $(250 \mathrm{mg} / \mathrm{kg} \mathrm{bw})$, C. soybean extract $(500 \mathrm{mg} / \mathrm{kg} \mathrm{bw})$, D. genistein $(0.3$ $\mathrm{mg} / \mathrm{kg} \mathrm{bw}$ ). Red arrows indicate CYP19 aromatase expression in Leydig cells and spermatogenic cells. 
Aryani et al.

Isoflavones have also been demonstrated to modify endocrine regulation of androgen production by altering serum LH levels (Lund et al., 2004). Therefore, the isoflavones or their metabolites can cause changes in the normal development of the hypothalamicpituitary-testicular (HPT) axis, which leads to changes in steroid production and circulation levels. The biosynthesis of testicular and male steroid hormone metabolism involves cascading cholesterol transport protein reactions and enzyme regulation by hypothalamic pituitary steroidogenic (Killian et al., 2003). The effect of isoflavones on hormone production and circulation levels has not been investigated in detail. However, some phytoestrogens have been shown to change the activity of the enzyme $3 \beta$-hydroxysteroid dehydrogenase (3 $\beta$-HSD) (Whitehead et al., 2002), 17 $\beta$-hydroxysteroid dehydrogenase (17 $\beta$-HSD) (Krazeisen et al., 2001), and 5a-reductase (Weber et al., 1999), which can affect androgen production in the testis. Phytoestrogens produced various physiological effects in humans and animal models. Their effects on the male reproductive system depend on the type of phytoestrogen, concentration, and model studied (Zoidou, 2008).

\section{Conclusion}

Exposure to methanol extract from soybean for 52 days could induce testicular damage in male rats and reduce Cyp19 aromatase expression in rat testis.

\section{References}

Arora, A., Byrem T.M., Nair M.G. and Strasburg G.M., 2000. Modulation of liposomal membrane fluidity by flavanoids and isoflavanoids. Arch. Biochem. Biophys. 373: 102-109.

Assinder, S., Davis R., Fenwick M. and Glover A. 2007. Adult-only exposure oh male rats to a diet of high phytoestrogen content increase apoptosis of meiotic and post-meiotic germ cells. Reproduction. 133: 11-19.
I.J. Biotech, Vol. 20, No. 2

Ballack, M.K., Gancarczyk, M., Sadowska, J., and Bilinska, B. 2005. The expression of aromatase, estrogen receptor a and estrogen receptor $\beta$ in mouse Leydig cells in vitro that derived from cryptorchid males. Europen J. of Histochemistry. 49: 395-402.

Bilińska, B., Wiszniewska, B., KosiniakKamysz, K., Kotula-Balak, M., Gancarczyk, M., Hejmej, A., Sadowska, J., Marchlewicz, M,. Kolasa, A., WendaRózewicka, L. 2006. Hormonal status of male reproductive system: Androgens and estrogens in the testis and epididymis. In vivo and invitro approaches. Reproduct. Biol. 6: 43-58.

Carani, C., Granata, M.R.A., Rochira, V., Caffagni, G., Aranda, C., Antunez, P., Maffei, L.E. 2005. Sex steroids and sexual desire in a man with a novel mutation of aromatase gene and hypogonadism. Psychoneuroendocrinology. 30: 413-417.

Carreau, S., Bourguiba, S., Lambard, S., Galeraud-Denis, L., Genissel, C., Bilinska, B. 2002. Reproductive system: aromatase and estrogens. Mol. Cell Endocrinol., 193(1-5): 137-143.

Carreau, S., de Vienne, C., Galeraud-Denis, I. 2008. Aromatase and estrogens in man reproduction: a review and latest advances. Adv. Med .Sci., 53(5),139-144.

Carreau, S., Silandre, D., Bourguiba, S., Hamden, K., Said, L., Lambard, S., Galeraud-Denis, I., Delalande, C. 2007. Estrogens and male reproduction: $\mathrm{A}$ new concept. Braz. J. Med. Biol. Res. 40: 761-768.

Cobellis, L., Reis, F.M., Driul, L., Vultaggio, G., Ferretti, I., Villa, E. 2002. Estrogen receptor alpha mRNA variant lacking exon 5 is co-ex- pressed with the wildtype in endometrial adenocarcinoma. Eur J Obstet Gynecol Reprod Biol. 102(1): 92-5.

Ellem, S.J., Risbridger, G.P. 2009. The dual, opposing roles of estrogen in the prostate, Steroid Enzymes and Cancer. 1155: 17486. 
Aryani et al.

Fritz, W.A., Cotroneo, M.S., Wang, J., Eltoum, I.E., and Lamartiniere, C.A. 2003. Dietary diethylstilbestrol but not genistein adversely affects rat testicular development. The J.of Nutr. 133(7): 2287-2292.

Ghosh, D., Das, U.B., Ghosh, S., Mallick, M., Debnath, J. 2002. Testicular gametogenic and steroidogenic activities in cyclophosphamide treated rat: a correlative study with testicular oxidative stress. Drug Chem. Toxicol. 25: 281-292.

Giwercman, A. 2011. Estrogens and phytoestrogens in male infertility. Curr. Opin. Urol. 21.

Hilaly, J.E., Israili, Z.H., and Lyoussi, B. 2004. Acute and chronic toxicology studies of Aguja iva in experimental animals. J. of Ethnopharmacol. 91(1): 43-50.

Kachhawa, J.B.S., Gupta, R.S., Sharma, K.K. 2012. Screening of isolated fractions of Dendrophthoe falcate methanol stem extract for its effects on reproductive function of male rats. Int. J. of Pharm. Sci. and Drug Research. 4(1): 84-87.

Kianifard, D., Hasanzadeh, S., and Kianifard, L. 2013. The study of time dependent administration of methylphenidate on the microscopic indices of spermatogenesis and sperm analysis in adults rats. J.Exp. Integr.Med. 3(2): 121-125.

Killian, J., Pratis, K., Clifton, R.J., Stanton, P.G., Robertson, D.M., O’Donnell, L. 2003. 5(alpha)-Reductase Isoenzymes 1 and 2 in the Rat Testis During Postnatal Development. Biol. Reprod. 68: 17111718.

Kim, S.H., Park, M.J. 2012. Effects of phytoestrogen on sexual development. Review articleKorean J. Pediatr. 55(8): 265-271.

Krazeisen, A., Breitling, R., Moller, G., Adamski, J. 2001. Phytoestrogens inhibit human 17B-hydroxysteroid dehydrogenase type 5. Molecular and Cellular Endocrinology 171: 151-162.

Lund, T.D., Munson, D.J., Haldy, M.E., Setchell, K.D.R., Lephart, E.D., Handa, R.J. 2004. Equol is a novel anti-androgen that
I.J. Biotech, Vol. 20, No. 2

inhibits prostate growth and hormone feedback. Biol. Reprod. 70: 1185-1195.

Marquez, S.R., Hernandez, H., Flores, J.A., Gutierrez, M.M., Duarte, G., Vielma, J., Rodriquez, G.F., Fernandez, I.G., Keller, M., Delgadillo, J.A. 2012. Effect of phytoestrogens on mammalian reproductive physiology. Tropical and Subtropical Agroecosystem 15: S129-S145.

Mesiano, S., Katz, S.L., Lee, J.Y., Jaffe, R.B. 1999. Phytoestrogens Alter Adrenocortical Function: Genistein and Daidzein Suppress Glucocorticoid and Stimulate Androgen Production by Cultured Adrenal Cortical Cells. J. Clin. Endocrinol. Metab. 84: 2443-2448.

Motofei, I.G., Rowland, D.L. 2005. The physiological basis of human sexual arousal: Neuroendocrine sexual asymmetry. Int. J. Androl. 28: 78-87.

Nantia, E.A., Travert, C., Manto, F.P.T., Carreau, S., Monsees, T.K., Moundipa, P.F. 2011. Effects of the methanol extract of Baselba alba L. (Basellaceae) on steroid production in Leydig cells. Int. J. Mol. Sci. 12: 376-384.

O'Donnell, L., Robertson, K.M., Jones, M.E., Simpson, E.R., 2001. Estrogen and spermatogenesis. Endocr. Rev., 22(3), 289-318.

O’Donnell, L., Robertson, K.M., Jones, M.E., Simpson, E.R. 2001. Estrogen and spermatogenesis. Endocrine Rev. 22: 289-318.

Ohno, S., Shinoda, S., Toyoshima, S., Nakazawa, H., Makino, T., Nakajin, S. 2002. Effect of flavonoid phytochemicals on cortisol production and on activities of steroidogenic enzymes in human adrenocortieal H295R cells. J. Steroid Biochem. Mol. Biol. 80: 355-363.

Prins, G.S., Korach, K.S. 2008. The role of estrogens and estrogen receptors in normal prostate growth and disease. Steroids. 73(3): 233-244.

Rice, S., Whitehead, A. 2006. Phytoestrogens and breast cancer - promoters or 
Aryani et al.

protectors? Endocrien-Related Cancer. 13: 995-1015.

Robertson, K.M., O’Donnel, L., Jones, M.E., Meachem, S.J, Boon, W.C., Fisher, C.K., Graves, K.H., McLachlan, R.I. \& Simpson, E.R. 1999. Impairment of spermatogenesis in mice lacking a functional aromatase (cyp 19) gene. PNAS. 96: 7986-7991.

Rochira, V., Zirilli, L., Madeo, B., Aranda, C., Caffagni, G., Fabre, B., Montangero, V.E., Roldan, E.J., Maffei, L., Carani, C. 2007. Case Report: Skeletal effects of long-term estrogen and testosterone replacement treatment in a man with congenital aromatase deficiency: Evidences of a priming effect of estrogen for sex steroids action on bone. Bone. 40: 1662-1668.

Sajjad, H. 2012.Toxicity effect of cisplatin treatment on rat testis tissue. Ann. Biol. Res. 3: 2297-2303.

Sakr, S.A. and Al-Amoudi, W.M. 2012. Effect of Ginger extract on deltamethrin induced histomorphological and immunohistochemical changes in testes of albino rats. Life Science Journal. 9 (1): 771-778.

Weber, K.S., Jacobson, N.A.,. Setchell, K.D.R, Lephart, E.D. 1999. Brain aromatase and 5alpha-reductase, regulatory behaviors and testosterone levels in adult rats on phytoestrogen diets. Proc. Soc. Exp. Biol. Med. 221: 131-5.

Weber, K.S., Setchell, K.D., Stocco, D.M., Lephart, E.D. 2001. Dietary soyphytoestrogens decrease testosterone levels and prostate weight without altering LH, prostate 5alpha-reductase or testicular steroidogenic acute regulatory peptide levels in adult male SpragueDawley rats. J Endocrinol. 170: 591-9.

Whitehead, S.A., Cross, J.E., Burden, C., Lacey, M. 2002. Acute and chronic effects of genistein, tyrphostin and lavendustin A on steroid synthesis in luteinized human granulosa cells. Human Reproduction 17: 589-594.
I.J. Biotech, Vol. 20, No. 2

Zoidou, E., Magiatis, P., Constantinou, M., Skaltsounis, A. 2008. Oleuropein as a bioactive constituent of functional milk and yogurt. Planta Medica 74: 62. 